\title{
Mining the Meanings and Pulling out the Processes From Psychology of Religion's Correlation Mountain
}

\author{
Loren D. Marks \\ Brigham Young University - Provo, loren_marks@byu.edu \\ David C. Dollahite \\ Brigham Young University, david_dollahite@byu.edu
}

Follow this and additional works at: https://scholarsarchive.byu.edu/facpub

Part of the Other Social and Behavioral Sciences Commons

\section{Original Publication Citation}

Marks, L. D., \& Dollahite, D. C. (2011). Mining the meanings from psychology of religion's correlation mountain. Psychology of Religion and Spirituality, 3, 181-193.

\section{BYU ScholarsArchive Citation}

Marks, Loren D. and Dollahite, David C., "Mining the Meanings and Pulling out the Processes From Psychology of Religion's Correlation Mountain" (2011). Faculty Publications. 4880.

https://scholarsarchive.byu.edu/facpub/4880 


\title{
Mining the Meanings and Pulling out the Processes From Psychology of Religion's Correlation Mountain
}

\author{
Loren D. Marks \\ Louisiana State University
}

\author{
David C. Dollahite \\ Brigham Young University
}

\begin{abstract}
This article illustrates how rigorous quantitative studies in three distinct and promising areas opened the door to additional related qualitative work. Using qualitative narratives from a landmark sample of 184 diverse religious families, the authors discuss and illustrate two research methods and that have been useful to them: triangulating data in the context of family, and seeking truth through progressive questioning. Next, consistent with the paper's primary purpose, the authors highlight three areas where the strong, correlation-based research foundation provided by quantitative social scientists of religion has created some prime, complementary opportunities for follow-up work by qualitative researchers. The specific areas illustrated include the following: (1) the case of religiosity and African American mortality, (2) the case of parent-adolescent communication, and (3) how shared religion helps marriages last. Recommendations for future research are offered.
\end{abstract}

Keywords: religion, family, qualitative methods

Over the past 20 years social scientific research on religion has increasingly examined several connections between religious involvement and other behaviors and psychosocial outcomes (Nelson, 2009; Paloutzian \& Park, 2005). Depending upon measurement, conceptualization, denomination, level of involvement, and other factors, some of these correlations are weak or moderate. Other correlations, however, are both significant and strong (for reviews, see Dollahite, Marks, \& Goodman, 2004; Mahoney, in press; Mahoney, Pargament, Tarakeshwar, \& Swank, 2001; Marks, 2005a, 2006). In this article, we argue and illustrate that these correlations provide rich "mining" opportunities for qualitative researchers. We recommend some methods-related strategies and offer examples of meanings and processes that have emerged from our work with a large, landmark sample. First, however, with offer a contextualizing overview of recent research on religion.

This article was published Online First May 16, 2011.

Loren D. Marks, School of Human Ecology, Louisiana State University; David C. Dollahite, School of Family Life, Brigham Young University.

Correspondence concerning this article should be addressed to David C. Dollahite, Brigham Young University, School of Family Life, 2054 JFSB, Provo, UT 84602. E-mail: david_dollahite@byu.edu
In their landmark volume Handbook of Religion and Health, Koenig, McCollough, and Larson (2001) systematically examine more than 1,200 empirical studies (and 400 reviews) on religion from the disciplines of psychology, demography, sociology, and medicine. On the whole, empirical data indicate that religion continues to be a psychologically, socially, and even biologically influential factor for many U.S. individuals (Koenig, McCollough, and Larson, 2001; Marks, 2005a)—indeed, survey data indicate that religion is "the single most important influence in [life]" for "a substantial minority" of Americans (Miller \& Thoresen, 2003 , p. 25). More specifically, religion tends to be a family affair, with $95 \%$ percent of all married couples and parents in America reporting a religious affiliation (Mahoney et al., 2001).

Psychology and religion researcher Annette Mahoney has systematically reviewed the published research on religion and couple/family relationships in the last 30 years. In a forthcoming review of the past decade of research (Mahoney, 2010), she states:

" $77 \%$ (79\% of marital and $76 \%$ of parent-youth) [research studies] used one or two items to measure religious variables (e.g., affiliation, attendance, selfrated importance, biblical conservatism). Further, there was heavy reliance on the self-report of one family 
member rather than multiple family members for both religious and family variables. Direct observation of family interactions was limited to two studies on marital and eight on parent-youth dyads. In addition, most studies used cross-sectional $(75 \%)$ rather than longitudinal designs (25\%), which makes causal modeling difficult. Consistent with U.S. norms, most samples in quantitative studies were predominantly Christian, and few focused on ethnic minority families" (p. 806, emphasis added).

Fortunately, there is emerging a body of excellent research in the psychology of religion that has begun to identify mediating and moderating variables in the relationship between religiosity and marriage and family life. This work takes us farther along the path to understanding the processes that influence how religion influences marriage and family life. However, we believe additional research is needed that (1) provides more in-depth information, (2) uses more varied methods, and (3) involves ethnically and religiously diverse samples. This paper describes the researchers' efforts to respond to these three identified needs through a landmark qualitative study, the American Families of Faith project. Although rich, illustrative data will be presented, this paper's primary purpose is to highlight how the strong, correlation- and observation-based research foundation provided by quantitative social scientists of religion has created some prime, complementary opportunities for follow-up work by qualitative researchers. It is also our aim to share and overview some of the tools that have proven helpful for us-tools that we hope will be useful or adaptable for others.

\section{New Directions in the Psychology of Religion}

The rapidly expanding body of social research on religion in the 21 st century offers researchers in the field the opportunity to consider several new directions and possibilities. Certainly, psychologists of religion will cover more territory if scholars head in various directions-as opposed to the whole camp figuratively marching due east in a single-file line. At present, the "disperse and explore" approach has been remarkably productive, as indicated by the literal mountain of predominantly correlational studies which both constitutes and buttresses the social scientific study of religion (Mahoney, 2010;
Paloutzian \& Park, 2005). As we rest on this modest mountain, the available view consists of correlations of religious involvement with an array of outcomes.

Indeed, "religion has a substantial independent impact on marriage, divorce, fertility, educational attainment, infidelity, crime, drug and alcohol consumption, to name but a few areas" (Stark \& Finke, 2000, p. 15). However, we have far less knowledge of the "whys, hows, and processes" that lie underneath the emerging correlational landscape (Dollahite \& Marks, 2009). In light of this interesting dilemma, our selected direction is straight down. We propose to do some mining and examine the explanations, meanings, and processes beneath recurring correlations. Our aim is to discover the meanings and motivations that drive those persons whose outcomes are most significantly impacted by religion-the highly religious. After a brief overview of sample and procedures from our research project, the focus will turn to two mining tools that have been useful. The balance of the paper will then be directed toward explanations and illustrations of how we have attempted to drill mines in three promising areas identified by quantitative research. Those areas include the following: (1) the case of religiosity and African American mortality, (2) the case of parent-adolescent communication, and (3) how shared religion helps marriages last. These example areas were selected for two reasons: (1) In each of these three areas, previous quantitative research sparked our interest and highlighted unanswered questions that we pursued qualitatively, and (2) these cases offer a diversity of race, developmental stage (elderly, adolescent, middle adulthood), unit of analysis (individual, parent-child dyad, marital dyad), and topical focus for the reader to consider. A desired outcome is that diverse readers will see that whatever their domain, there are promising areas to explore, and that these three cases are only a small sample among countless rich opportunities. Our hope is that our trials, errors, and successes will be of use to our fellow researchers-and that in addition to the three intentionally diverse examples we offer here, that other promising areas will be mined by others. 


\section{Method}

\section{Sample}

The sample for the project ( $n=184$ families, 445 individuals) was purposive and was characterized by the following: (1) religious diversity (Christians, Jews, Mormons, and Muslims), (2) a high level of religious commitment (as reported by referring clergy and the participants themselves), (3) racial and ethnic diversity (including an oversampling of minority and immigrant families), and (4) a wide range of socioeconomic and educational levels. This study also moves beyond most related studies by interviewing married mothers and fathers (and adolescent children, when possible) from the same family. Couples are typically in their mid/ late-forties and had been married an average of about 20 years. All couples have at least one child ( $\mathrm{M}=3.3)$.

Geographic locale. The sample includes families residing in all eight regions of the United States: New England (MA, CT), the Northwest (OR, WA), the Pacific region (CA), the Mountain West (ID), the Mid-Atlantic (DE, $\mathrm{MD}, \mathrm{PA})$, the Midwest (OH, WI), the Southern Crossroads region $(\mathrm{OK})$, and the South (FL, LA). Geographic locale is an important consideration given regional variation in U.S. religiosity (Silk \& Walsh, 2006).

Religion. There is substantial religious diversity in the United States. Given that the Abrahamic (Christian, Jewish, Mormon, and Muslim) faiths have some broad similarities on how deity is viewed (monotheistic), as well as a shared emphasis on marriage and family, we limit our sample to these faiths. Our desire was to select a sample of religions broad enough to allow diversity and comparison but small enough to allow us to study and have first-hand experiences with each. We had 111 Christian families (including Catholic, Mainstream Protestant, Evangelical Protestant, Orthodox, and New Christian Religious Traditions), 31 Jewish families (including Hasidic, Orthodox, Conservative, and Reformed Traditions), 22 Mormon (also called Latter-day Saint or LDS) families, and 20 Muslim families. Additionally, in our efforts to better understand these faiths, we personally attended many faith community services and activities for these religions, met with and interviewed their clergy, and studied the primary sacred texts of each faith in their entirety.

Race/ethnicity. Of the families, 32 were African American, 17 were Asian American, 15 were Native American, 13 were Latino, 11 were Middle Eastern, four were East Indian, and one was Pacific Islander-with the balance of the families (91) being Caucasian. Thus, 50.5\% (93) of the families represented an ethnic or racial minority.

\section{Procedures}

After IRB approval from the researchers' institutions and informed consent by the participants, qualitative, semistructured interviews were conducted based on a $20+$ question schedule that addresses marriage, parenting, religious beliefs, religious practices, faith community, stress and coping, and other issues. A vital element to the qualitative design in this study is the narrative approach (Josselson \& Lieblich, 1993). On a basic level, the narrative approach encourages the participant to relate real-life experiences (personal narratives) as illustrations of constructed meanings or beliefs (as explained in more depth later). Narratives and explanations help portray what is meaningful to the participant. Through narratives, personal and shared family meanings and experiences stretch backward and forward in time, thereby offering a fluid motion picture of process.

\section{Mining With Qualitative Interviews: Explanations and Illustrations}

In this central section of the paper, we will focus on two mining tools or methods; then we will address and share some of the "gems" that we have found using these methods. We reference a dozen or so published (or in press) studies we and our students have completed from these data.

\section{Triangulating Data in the Context of Family}

The first mining method we will address is triangulating data-more specifically, triangulating in the richest context of lived religion, the family. Handel (1996) argues that most family research is not truly family research because it 
focuses exclusively on one relationship (usually the mother-child or marital relationship only) and often includes data from only one family member. As indicated at the outset of this paper, Mahoney (2010) has found a similar trend in social research on religion. Further, qualitative research on religion and family experience has typically been limited to specific, samegendered groups [for example, Kaufman's (1991) and Davidman's (1991) work with Orthodox Jewish women; or work with Latter-day Saint fathers (Dollahite, 2003; Dollahite, Marks, \& Olson, 1998; Marks \& Dollahite, 2001)]. These constraints are unfortunate. Given that women and men frequently view religion, family, and culture in different ways, the inclusion of maternal and paternal perspectives is essential (Ozorak, 1996; Palkovitz, 2002).

With reference to the typically limited (one participant per family) approach to data collection Handel (1996) contends, "No member of any family is a sufficient source of information for that family" (p. 346). We agree with Handel's assessment and subsequently interview mothers and fathers from the same families. This approach provides triangulation through three data points: (1) the mother's reports, (2) the father's reports, and (3) the interviewer's observations. Where approved by the IRB, adolescent/young adult children have been interviewed as well, thereby adding a fourth participant (or more, when more than one adolescent child was interviewed). These methods model the research approach Handel (1996) and others advocate and help us offer depth, breadth, and multiple perspectives on how and why religious faith influences personal, marital, familial, and social life. Below, we offer examples of juxtaposed narratives from spouses that (together) offer a depth that would be difficult to reach with only one spouse or the other. Joseph, a nondenominational Christian father of four, reflected:

"Kids just want to know the truth and you have to represent that in a way that's meaningful and in a way that's real. Your kids live with you, they see you. They see if this is a Sunday morning thing or a 24[hours a day]-7 [days a week] thing. When Dad slams his thumb in the car door, what does he do? When something goes wrong, does he freak out or does he have faith?"

Julie, Joseph's wife, later mentioned:
"In our family [Joseph's] an excellent role model. The kids need to be able to look up to him and see God in his life [so] that they'll want to pattern their lives after him. It's always great for kids to be able to look up to their Dad and see someone that they respect. I've seen him changing over the years. He loves the Lord and wants to do what pleases Him ... modeling what he sees as being valuable for the kids to see. He has an important role in being like Jesus to the kids. A lot of our understanding of who God is comes through fathers, because God is presented as a father in the Bible. If a kid grows up having a father who is loving and kind and supportive and strong, I think it is easier for them to understand God and who He is."

Julie mentioned the example Joseph sets for their kids, but he later mentioned the influence Julie's example had on him. He reflected:

\begin{abstract}
"I see [Julie] get up every morning and take time to read scripture and pray and I just see that it's not separate from the rest of her day and that it influences the way she does [everything], the way she interacts with me and the kids and everybody in the community. It's central, it's pervasive. [it makes me want to do likewise]."
\end{abstract}

Joseph would later conclude by saying:

\begin{abstract}
"There's something that, when as a family your hearts are pointed together toward the same thing, and it's God, then parenting styles and economics and space and food and disagreements and hassles and joys and celebrations and all that other stuff, it works different, it seems different, it feels different. Our family isn't about [materialistic] things. Our family [members] are all oriented in the same way. Christ is king, He's the center, He's what it's all about. I don't know how to convey to you that ... yes, our faith informs our relationships and everything about us."
\end{abstract}

From Julie and Joseph we learn that she appreciates his efforts to model his faith for their children, while he mentions the effect her quiet example and devotion have on him. The result is a faith-oriented, "Christ-centered" family. This interplay is likely to be lost in a "one respondent per family" approach.

In a similar example, an African-American Baptist couple shared the following exchange that integrated faith and marriage:

Earl: "Even though we are married and we're supposed to be one..."

Tiffany: "We're just different!" [mutual laughter]

Earl: "We're individuals. We battle, you know, and a lot of times she don't like the differences in me, and a lot of times I don't like the differences in her. But we both believe that marriage is a sacred vow, it's a vow we took before the Lord that we're gonna honor. We 
said the same vows, 'For better, for worse, in sickness and health, for rich, for poor."'

From Earl and Tiffany, we see playful banter that acknowledges differences between them, but we also see a celebration of their sacred view of marriage and the vows they made almost 30 years earlier.

We now offer a third example of the synergistic results of seeking multiple-member interviews and insights. A Conservative Jewish mother named Sarah who was working hard to help build a faith community for her children told us the following:

"There is a sacrifice of time. There was a period of time where I was spending easily 20 hours a week in volunteer and religious activities, and at that point I felt it was a sacrifice because it took away from family time and it was hard. I had to see the big picture and remember I was doing it [for] my kids and wanting to build a [Jewish] community for them in the future here in this area. But in the short term though, they were unhappy because I had so much time in meetings and on the phone and on the computer and doing things like that, so I backed off."

Her husband Seth later expressed the following:

"I don't like always having her out at nights, I like to have her home, but it's important to her. So it's, 'Watch the kids tonight, I need to go to a [synagogue] board meeting.' My only response is, 'Okay.' I'll never stop her from that, I will never get in the way of her faith. I appreciate it on another level-the world needs people like her. If it were up to people like me to keep [faith] going, the world would be in sad shape. I've teased her often that she's off to save the world. She's passionate about it."

From Sarah and Seth, we see that religious involvement can involve personal and marital sacrifice (a recurring theme in many interviews). One can sense Sarah's conviction and commitment to her cause, as well as Seth's respect for, and support of, Sarah's involvement-although we see a mutual price being paid.

Near the outset of this paper, we presented a call for research that (1) provides more in-depth information, and (2) uses more varied methods (Mahoney, 2010). The narratives of the three couples we just heard from each provided "more in-depth information," largely because of the fact that we interviewed more than one spouse ("used more varied methods"). Our own shift from solely interviewing fathers (earlier in our careers) to interviewing families has been invaluable for us, and within-family triangulation is a tool we recommend as a depth, breadth, and validity enhancer for qualitative and quantitative social scientists examining religion. We now turn to a second useful tool.

\section{Seeking Truth Through Progressive Questioning}

Researchers are well aware that in the language of $n$ (sample size), more is better. Our preceding recommendation similarly posited that interviewing multiple members per family yields both more volume and quality than interviewing one member. Our second recommended practice in social research on religion, progressive questioning, is a variation on this "more is better" theme. To set the table for this recommendation, we note the recurring finding that Americans tend to overreport church attendance-and likely other religion-related variables as well (Hadaway, Marler, \& Chavez, 1993). This is a frustrating commencement point for social scientists who examine religion because regardless of sample size, statistical power, and sophistication of modeling, if we commence with incorrect (i.e., exaggerated) data, we are at a profound disadvantage.

Pauline Boss (1980) has argued that to carefully examine a phenomena we should examine prototypical examples and cases. In the psychology of religion, this seems to imply that special attention should be paid to the highly religious (e.g., prototypical Christians, Jews, Muslims, etc.) - a strategy we use (Dollahite, Layton, Bahr, Walker, \& Thatcher, 2009; Dollahite \& Lambert, 2007; Dollahite \& Thatcher, 2008; Goodman \& Dollahite, 2006; Lambert \& Dollahite, 2006, 2008; Layton, Dollahite, \& Hardy, 2011; Marks, 2004, 2005b; Marks \& Dollahite, 2007, 2010). With this said, how do we know whether someone is truly highly religious or not? How can we maximize the validity of reported data on religiosity so that we can more closely approximate the "truth" in our subsequent calculations, correlations, and conclusions?

Our first strategic response is that we use a progressive, triangulated sampling approach. We first contact clergy for select referrals of highly religious (prototypical) families from their congregations. We then contact those families and ask whether both the wife and husband 
classify themselves as highly religious. Interestingly, on rare occasions a parent will say something like: "Yes, I go to church weekly, but it is out of obligation; I am not actually a religious person." Only after an affirmative triangle is completed is the family interviewed. In sum, triangulated sampling for highly religious persons and families offers two checks beyond traditional self-report.

During the interview itself, validity ("truth") remains of utmost importance. Here, social scientists can benefit from elements of the crossexamination approach used in law. While we do not advocate an aggressive or confrontational style, we see wisdom in the practice of progressive questioning that involves additional, delving questions that follow-up initial responses. Here are some examples of that approach from our interviews:

Interviewer: Are there any religious practices that are special to you?

Aida (Latina Mormon mother): Yes.

Interviewer: What are some examples?

Aida: Going to church on Sundays as a family and receiving the sacrament is special because it brings you back to when Jesus Christ, our Savior, suffered for our sins. Praying together as a family and reading the scriptures ... together is probably the best.

Interviewer: Why is that special to you?

Aida: It feels right. It feels good. It feels like this is what every family should be doing. I' $m$ grateful to be able to do that. If my family that I grew up with ever would have done that it would have been a fond memory that I would have held, but we never did. [Our family now] should pray more, but when we kneel together and holds hands as a family, it brings the spirit in [our home] and makes the children feel right, and that this is what they need to do with their familiesand I'm sure they'll remember it. It's special.

Interviewer: Does your faith help you cope with challenges?

Rebecca (conservative Jewish mother): Oh, definitely.

Interviewer: Can you tell me about a specific time?

Rebecca: [When] my father passed away that was probably the biggest challenge of my life. I mean, it was just an automatic thing to go to synagogue and to look at death from a Jewish perspective. I mean, that's Judaism's strength. I think that after September 11, with the [terrorist] attack, we instinctively went to synagogue the next Friday night and it was packed. I think that's just how we cope.

Interviewer: Has your spouse influenced your faith?
Kristen (Muslim mother): Yes.

Interviewer: How?

Kristen: [When we were dating], I was mesmerized by how dedicated [my future husband and his brothers] were to their Mom and Dad, and it wasn't just their family. The people who were true to Islam [were the same]. [Also], how many college guys do you see who would excuse themselves on a date and say, "Excuse me, I have to go pray." We were at the beach, and he would take out his prayer rug and pray. People were walking by and staring. I was used to beer-drinking and [ungentlemanly behavior]. [His example] made me wake up.

In each of the above instances, the first question the interviewer asks seeks to establish whether or not religious faith is influential at a practical personal or familial level. However, if an affirmative answer is given, the interviewer immediately asks for specific examples, experiences, and explanations. This approach is taken from the outset of the interview and participants quickly learn that any affirmative response opens the door to specific, progressive questioning. By requiring participants to validate, narrate, and explain the responses they offer, we believe that we are more likely to end up with more valid (less exaggerated) data and more accurate connections and conclusions.

To this point, we have discussed and illustrated two keys to mining data with depth: (1) triangulating in the context of family, and (2) seeking truth through progressive questioning. We now leave our discussion of two useful mining tools and focus on the treasure itself.

\section{Whys (Meanings), Hows (Processes), and Qualitative Causality}

We mentioned earlier in this paper that our purpose in mining is to examine the meanings, motivations, and processes beneath the recurring findings that constitute "correlation mountain" or the vast body of studies showing correlational links between religion and a variety of important psychosocial variables. Unfortunately, qualitative research cannot offer generalizable, comprehensive, and objective explanations. However, our participants do offer some specialized, partial, and subjective explanations of several of the processes involved. We now move to three examples of participant explanations of meanings and processes that link religious involvement with various outcomes. 
Example 1: The case of religiosity and African American mortality. There are few religion-related findings as striking as Hummer et al.'s (1999) finding that African Americans who attend worship services twice a week live an average of 13.7 years longer than their nonattending counterparts. This study-which received the highest possible rating ('10') for methodological rigor (Koenig, McCollough, \& Larson, 2001, p. 562)-does control for and eliminate several likely sociological explanations, but Hummer et al. (1999) offer no datadriven explanations for the correlation. Fascinated by this unanswered question, we included some related questions on our interview schedule for a group of $60+$ African Americans the first author was preparing to interview. Most of these participants were "insiders" on two levels: first, they were African American, and second, most were highly religious. Accordingly, we felt their explanations of the processes underlying the church attendance-to-longevity linkage were of value. The participants' explanations and examples fell under six thematic headings identified by our research team (see Marks et al., 2005). In connection with the theme active faith involvement helps keep them alive, one mother in her late 50s explained the following:

"[Y]ou look at some of the Baptist churches, you have the old ladies (like my Mom, who is 85) who barely move, and they're still bringing them back every Sunday, for everything. They're a part of that church and that keeps them alive, because they're part of something that's vital."

In connection with the theme that addressed avoiding negative coping when faced with life's problems, participants made comments like:

Keisha: I think some people do [alcohol and drugs] because they don't have a strong religious faith, and they don't know where to turn [when things get tough], so they turn to the bottle, alcohol, or drugs.

James: Not that people in church don't get involved with drugs or other things like that, but a lot of times the street life will consume [those who aren't in church] and their bodies become so worn by the lifestyle, or they develop some of the social ills, [and may even commit] suicide [because] they don't have peace. [Life] is very incomplete.

Given the inner-city context most $(80 \%)$ of these participants were living in, another emergent theme was that of evading violence that is prevalent in "the street life":
Ty: The reason why [religious persons live longer] is because a religious [person] will stay away from the things that will hurt them. A person that's not going to church, they could ... be among [the wrong] individuals, get shot and die.

Maurice: The ones who don't attend church are out there committing crimes, and they're dying at a young age.

Other themes identified the dangers inherent in "giving up," or in having an absence of hope-as manifested by withdrawing from the spiritual and social support of a faith community or "church family," as Annie and Shayla discuss:

Annie: You know, people tend to isolate themselves from the rest of the family [when they are in a state of depression], which is stressful for the rest of the family [meaning both "church family" and biological family]. I think one of the worst things that they do is, they give up on faith. [My brother] stopped going to church, probably stopped praying. The worst thing that people could do is stop going to church, lose contact with their faith, not staying in contact with those people that would normally be a support mechanism for them, and then [instead, turning to] things like drugs and alcohol and violence.

Shayla: They just give up. They stop coming to church, and to me, you stop coming to church ... that's your [hope], you should continue coming to church, and ... I guess they have no hope ... that's what I feel, they have no hope. They think that they can fix it themselves, and you can't fix it by yourself. You have to be with people that are of like faith, you have to have that fellowship, you have to have that fellowship with others [to thrive].

A final theme emphasized how, through what participants called "the power of prayer," they were able to cast their cares on the Lord and "lay their cares down":

Florence: I think knowing how to give all those hard times [to God] helps ... "Lay [on] God your burdens, right, lay your cares down because He cares for you." [People who have God], they've learned how to not let the burdens and the stresses of today wear them down and bear them down.

Jacquie: As a Christian person, we know that we can pray. We don't need all these other things (like alcohol and drugs) to get us through. The power of prayer is enough, and I think that being able to just go to God in prayer, we get the sense of peace and the sense of relief that we're searching for when we're going through difficult times, so I think that's the difference.

Again, we were mining for explanations of the church attendance-to-longevity correlation and we received several. A careful review of the 
emergent themes indicates that the explanatory themes were not solely psychosocial, nor were any of the explanations solely religious. Indeed, each of the themes is interactive and blends religious and psychosocial elements. For example, (1) Aged members reportedly live longer not only (or even primarily) because of the religious meaning and healing available at church, but because they are venerated, valued, and respected there; (2) Church involvement, according to these insider experts, correlates with lower mortality not only through providing positive programs but through eliminating or minimizing involvement in the alternative dangers of "the street life" (drugs, alcohol, gang activity, etc.); (3) Even prayer, as meaningful as it was for many participants, was beneficial for them not only for resulting help from God but because psychologically and spiritually coping through prayer is preferable to coping by abusing alcohol and drugs.

In sum, we are left with psychosocialreligious hybrid explanations that seem plausible and reasonable to both the believer and the nonbeliever. However, whether the reported findings result from divine "direct effects," from indirect social forces, or both, we have some treasure to consider and examine. We now move to a second parallel example; one that moves us from the individual bio-psycho-social level of analysis to a consideration of parentchild relationships and processes.

Example 2: The case of parent-adolescent communication. Dollahite and Thatcher (2008) studied conversational processes between parents and their adolescent children and found that when parents and teens talk together about religious issues, or about other matters with religious implications, there is potential for strong positive or negative emotion in both parent and child. They found that parentadolescent conversations were more emotionally positive for youth and parents when they were youth-centered, and less emotionally positive when parent-centered. For example, Chad, a 12-year-old, Episcopalian said:

\footnotetext{
"Sometimes I ask a question and then I think that they go too far because they start talking too much. And then I say that I don't want to discuss it anymore and I try to walk away and then they have me come back in and I'm, like, really mad."
}

Haley, a 14-year-old Latter-day Saint was irritated that her father always spoke of reli- gious principles: "He always, for every situation, even something [like] a math problem, he can relate a scriptural principle. And it can get really annoying."

Rachel, a Hasidic Jewish mother, explained that even when, as parents, they initially gave their children a chance to talk, but then took over the conversation, the children did not always listen. She said:

"We have relaxed conversation at the table, and then,
we, either my husband or myself, after 10 minutes [or
so], we tell the kids to hold onto their chair, just try to
listen. And they don't always listen as well as we'd like
them to listen and they sometimes are like 'blah, blah,
blah"."

Jack, an 18-year-old Baptist, told how his friends' parents neglected the parent-child relationship while still trying to transmit beliefs:

\begin{abstract}
"I've seen [how] some of my friends have acted, where parents are slamming Bible verses in their face, and really not loving them, not helping them grow. It's more like a forceful thing, at unnecessary times. Wh[at] really would have been helpful [would have been] just for them to sit down and talk with their kid.
\end{abstract}

Conversely, both parents and adolescents reported that when religious conversation was focused on the adolescent child's needs and interests, the adolescents were engaged, interested, and enjoyed discussing religion. Alecia, 20, said she enjoyed casual conversation where she could talk. She explained:

\begin{abstract}
"If it's a one-on-one conversation, it's usually pretty interesting. It's interactive. I enjoy talking about religion. Most of the time when we're just talking as friends more than anything, like on a casual basis, it's usually pretty cool. I'll say something to [my Mom] about religion and she'll be like, "Yeah, that's awesome. I have a story that goes with whatever you were talking about." And I'm like, "Oh, that's really cool." And you know we can talk about it casually."
\end{abstract}

Not surprisingly, religious conversations also addressed how religious beliefs, values, and practices informed issues of daily life such as peers, dating, family, media, school, politics, and current issues. Interestingly, parents from both progressive and traditional faith communities emphasized the value of youth-centered conversational processes over more "hierarchal" or "preachy" or "parent-centered" approaches. In sum, a substantial body of literature addresses parent-child religious transmission (Marks, 2006); however, the above research offers insights into how this 
transmission/transaction may best be negotiated. As in the previous example of AfricanAmerican longevity, through in-depth examination of a previous point of exploration we can learn more about psychological-religious meanings, motivations, and processes.

Example 3: Shared religion helps marriages last (but how?). Our first "mining" example included explanations of longevity among highly religious black Americans. Our third and final example involves religion-related longevity of a different kind, marital longevity.

Recent reviews indicate that married persons who are involved in the same faith as their spouse tend to have longer, stronger, happier, and more satisfying marriages (Chatters \& Taylor, 2005; Dollahite, Marks, \& Goodman, 2004). However, we are left with few databased explanations. This is an issue we addressed with our sample of 184 highly religious families, families where the spouses are jointly involved in their faith communities. With 184 wives and 184 husbands from marriages whose average duration exceeded 20 years, our sample draws on more than seven millenia of combined marital experience $(368$ individuals $\times 20$ years $=7,360$ years). We thought we would do some mining and see what underlying explanations they would offer regarding the shared faith-to-long marriage correlation.

A Jewish mother named Sarah explained how the Friday night ritual of welcoming in the Sabbath with the lighting of candles and the Sabbath meal have added a depth to her relationships with both her husband and her children (Marks, 2004). She explained:

"(T)he Sabbath [ritual/meal] has a meaning of its own. [A]fter [the meal], I always say a prayer of thanks for my children. [The ritual] means that at least once during the week I'm having a moment of thankfulness, where no matter what else is going on that may not be good, I'm very focused at that time on what I'm thankful for. We don't do any work. It's a time given to relaxation and being together. When we sit across the table from each other, my husband and I, and the Sabbath candles are lit, and I see the kids, there is something I get from that that is so deep. It's just a feeling that [all is right in the world] ... it doesn't matter what else is going on. Right in that circle. It's awe-inspiring."

Sarah's constant references to her husband and children-feeling close to them, praying with them, blessing them, being grateful for them-culminate in her expression that the
Sabbath meal offers her something of great depth in the family context. Sarah's husband similarly summarized, "I don't know that the Sabbath meal is a religious experience for most people, but for me it's the heart of religion." Yet, the rituals that unite can also divide. One Jewish father lamented:

\begin{abstract}
"(Two of my brothers) married persons out[side] of the faith and I don't think they'll have much religion of any sort now. I don't think they'll have much Christianity or much Judaism. I see the family dynamics, the relationship between my parents and them. I mean, my parents love them very much but it hurt my parents. When we're all together, although we love them all and we get along with them all, we see the differences. When we are all sitting around at the holidays [which are loaded with rituals] they [the non-Jews] just don't get it."
\end{abstract}

Lambert and Dollahite (2008) found that religious beliefs and practices helped couples: (1) to include God as the "third cord" in their marriage which bound couples to each other with strong ties, (2) to believe in marriage as a religious institution that can and should last, and (3) to find meaning in committing to marriage. Thomas, a Presbyterian father, said, "I believe it is a covenant. It's a three-way covenant between us and God and we believe that we're one, we're one flesh, we're one in union." Matt, a Lutheran father, also used the "threefold cord" metaphor to indicate his belief in marriage as an institution that should not be dissolved. $\mathrm{He}$ stated:

\footnotetext{
"You go to Ecclesiastes and it says that a cord of three strands is not easily broken. I think that the spiritual belief I have is that God through Christ is our example of what marriage and a family should be like. And I think that we take seriously where it says that God hates divorce, and we also take seriously where it says the two shall become one and we try to be."
}

Jennifer, a Latter-day Saint mother, indicated that her religious beliefs encouraged her to look beyond "until death do you part":

\footnotetext{
"Well, we believe that families are together forever and we go to the temple and are sealed to one another so that we will be together forever, and I think that that's Heavenly Father's plan to have us be together forever. That's the common goal we have together, to be together forever, to keep that promise we made to each other: to be committed to each other and to be together forever."
}

Michelle, a Christian Scientist mother, explained how her faith helped her to stay com- 
mitted to marriage during difficult times in her marriage:

\begin{abstract}
"We've been married over 19 years and sometimes your spouse drives you crazy, but you love him. And sometimes you just have to see him as God sees him. Not sometimes-all the time, actually. [If you can remember that] the set of wonderful qualities that you married him for, it just helps you get over the tough spots."
\end{abstract}

Continuing on the theme of "tough spots," Lambert and Dollahite (2008) found that shared religious beliefs and practices helped couples: (1) avoid conflict, (2) resolve conflict, and (3) work toward relational reconciliation. In connection with the preventive approach of avoiding conflict, a Baptist mother named Debby stated the following:

"I think that the more shared perspective on life that you have, the less inherent conflicts [you have] to begin with. So I think having a shared faith is important in that sense, in both the big picture, and hopefully, the smaller picture. But I think for me, somehow, my faith affects how I view conflict."

Some couples found that prayer helped them to resolve conflict. Alex, a Puerto Rican Pentecostal Father, stated the following:

"[When] a crisis would come, we'd feel that we'd need to pray together, we['d] feel that there's a lack of communication between us. As a matter of fact that happened recently. So we pray together. When we feel that something's trying to divide [us] we'll pray together, [and] it strengthens [us], or at least alleviates the problem."

After conflict, couples stated that their religious beliefs and practices assisted them in the necessary but often difficult process of offering and accepting forgiveness. Stuart, a Latter-day Saint father, said:

\footnotetext{
"One of the basic teachings of the Savior is forgiveness, so if you want to be forgiven, the Bible teaches that you need to forgive other people. And obviously we're imperfect and we want to be forgiven, and so I think both of us bring that idea or that principle into our marriage relationship and we see that we have to be willing to forgive the other person and that influences our ability to maybe forgive a little bit sooner than we normally would have."
}

In addition to offering the above explanations regarding religion's influence vis-à-vis preventing and resolving conflict, our work has also found that religious belief and practice reportedly promotes marital fidelity in four important ways: (1) religious belief and practice sanctified their marriage and thereby improved marital quality, which indirectly promoted fidelity; (2) religious vows and involvement fortified marital commitment to fidelity; (3) religion strengthened couples' moral values, which promoted fidelity in marriage; and (4) religious involvement improved spouses' relationship with God which encouraged them to avoid actions such as infidelity that they believed would displease God (Dollahite \& Lambert, 2007). Mitch, a Methodist father described his experience with vow making:

"[When I talk about fidelity], I mean fidelity to a vow;
and making a vow in front of God and the family.
That's pretty serious living up to that. And that's in our
vows, that promise was indeed caring for each other
through all of life's surprises. And speaking those
vows in front of her ten brothers raised fidelity on the
list."

For our participants, clear and continual discouragement of infidelity by their faith communities reportedly made a difference as well. Brent, a Jehovah's Witness father, said the following:

"Well, we mentioned before [in our interview] about
[marriage] being a permanent bond, that Jehovah God
hates divorcing because that breaks the marriage bond.
And Jesus also said that adultery would be something
that would, could, break the marriage bond."

Angie, a Muslim convert and mother of two, spoke not only of religious practices and their meaning but also of detrimental practices that she felt her faith protected her and her husband from, namely extramarital affairs. Angie's parents had divorced over infidelity issues years before, and she was especially sensitive to this issue. She explained:

\begin{abstract}
"My husband knows my worst fear before we got married [and before I was Muslim] was that I would divorce. I've seen a lot of men that when things get tough, they take off. [I was afraid] that my husband would leave or I would leave, [have] an affair. But now, I can sit here and look you in the eye [and tell you] I have no fear that my husband will have an affair. I know him. I know he lives his religion."
\end{abstract}

Later in the interview, Angie's husband Omar shared the following narrative that seems to illustrate why Angie displays such confidence in his fidelity. He reported:

\footnotetext{
"At work, our offices look out on to the parking lot. Every morning, all the engineers gather into this one guy's cubicle at 7:45 [as the women start to arrive] and say, "Ah, look what she's wearing. She looks good!"
} 
Typical, it's a normal thing between guys. But by saying these things you are degrading that woman, you are gossiping. Knowing that these things will be written [in my heavenly book] prevents me from [participating] and from that your entire behavior is changed. [Instead], you are sitting in your office doing your work, which is what you are supposed to be doing."

Omar had previously offered a detailed explanation of his spiritual belief that our misdeeds will be written in a personal book of life that will one day be opened before the world and that this belief keeps him in constant check. Note that Omar's faith is expressed not only in sacred practices like prayer but also in his avoidance of behaviors that are not congruent with his professed beliefs (Marks, 2004, 2005).

In summary, existing data indicate a linkage between shared involvement in religion and more durable, higher quality marriages, but little is know about why. The couples we have interviewed identify several factors, including the following: (1) sacred, meaningful family rituals and practices that unify the marriage and family, (2) a shared belief system and worldview, (3) a view of God as the "third cord" in their marriage which binds couples to each other with strong ties, (4) a specific belief in marriage as a religious institution that can and should last, (5) a focused effort to find meaning in committing to marriage, (6) a desire to work to prevent problems in the relationship, (7) an ability to draw on sacred beliefs and practices to resolve conflict, and (8) a religiously based motivation to work toward relational reconciliation. As in the previous example of mining for explanations regarding the tie between church attendance and African-American longevity, as we dig deeper into the religion and marriage connection we find several underlying meanings, motivations, and processes at work.

\section{Limitations}

Before concluding, an important set of counterpoints should be noted. The three examples of religious influence (increased AfricanAmerican longevity, positive parent-adolescent communication, and marital stability) we highlighted in this paper were all positive in nature. Our focus on the positive fails to capture much of the needed nuance and complexity surrounding religion. With respect to the three examples we use, the following should be noted: (1) Al- though church attendance correlates with longevity, some expressions of religious belief proscribe medical attention, which can lead to higher mortality rates (Koenig et al., 2001); (2) Although parent-child communication/interaction regarding religion is largely positive when it is child-directed, it can be counterproductive when it becomes adult-dominated or coercive (Lee, Rice, \& Gillespie, 1997); (3) Although shared religiosity tends to correlate with marital stability, unshared religiosity has been correlated with relatively high rates of conflict (Curtis \& Ellison, 2002) and divorce (Lehrer \& Chiswick, 1993). As the field progresses we will learn more about why and how religion helps, as well as why and how it can be dangerous or damaging (Marks, 2006).

\section{Conclusion}

Given the salience of religious experience in the lives of those we have interviewed and the "substantial minority" of Americans like them (Miller \& Thoresen, 2003, p. 25), psychologists, pastors, clinicians, and social researchers seeking a comprehensive understanding need a working awareness of recent research on religion. Religion is not (or at least should not be) a fringe issue in psychology. Even so, the late David B. Larson warned that religion was a dangerous "antitenure" topic in the academy as recently as 1995 (cf. Marks, 2005a).

In this article, we have considered new (21st century) directions in the psychology of religion. To restate, we now stand on a solid foundation of correlations linking religious involvement with a lengthy list of psychological (as well as sociological, familial, and medical) variables. Our chosen "direction" is to dig downward at promising locations identified by previous researchers. We are not suggesting that researchers should throw away the surveying equipment and start drilling mineshaftsmining is a project with no guarantees and myriad hazards. Indeed, in terms of professional risk, commencing a qualitative research expedition is perilous for an untenured scholar and doing so in the psychology of religion is riskier still.

While we are not calling for others to follow our lead, we are making the three following assertions: (1) We resonate with Thomas' (1988) view that "social scientists must focus on 
the religion and family interface if they wish to more fully understand the human condition" and that "the best research and theory will be that which analyzes [religion and family] simultaneously" (p. 373). One effective way of doing this is to interview multiple members of the same family, thereby triangulating data in the context of family. (2) Given the paramount consideration of validity and truth in data collection, we recommend seeking truth through progressive questioning - moving beyond initial responses to probe for reinforcing, supporting information. Further, we note that neither of the above mining tools is exclusively for qualitative research. Indeed, triangulation, family context, and progressive questioning can all be adapted for use in quantitative research and mixed-method approaches as well (cf. Lambert \& Dollahite, 2010). (3) Mining adds a third dimension to the traditional surveying approach. We are not arguing that mining should be the new direction in 21st century psychology of religion, or even that it should be a primary one. However, we are reporting that as we have applied these mining tools in our own in-depth interviews with 184 highly religious families, we have discovered a few treasures-insights regarding whys, hows, and processes. Indeed, the rewards were rich enough to justify mining downward as one of the important directions in the psychology of religion.

\section{References}

Boss, P. (1980). The relationship of wife's sex role perceptions, psychological father presence, and functioning in the ambiguous father-absent MIA family. Journal of Marriage and the Family, 42, 541-549.

Chatters, L. M., \& Taylor, R. J. (2005). Religion and families. In V. Bengtson, A. Acock, K. Allen, P. Dillworth-Anderson, \& D. Klein (Eds.), Sourcebook of family theory and research (pp. 517-522). Thousand Oaks, CA: Sage.

Curtis, K. T., \& Ellison, C. G. (2002). Religious heterogamy and marital conflict. Journal of Family Issues, 23, 551-576.

Davidman, L. (1991). Tradition in a rootless world: Women turn to Orthodox Judaism. Berkeley, CA: University of California.

Dollahite, D. C. (2003). Fathering for eternity: Generative spirituality in Latter-day Saint fathers of children with special needs. Review of Religious Research, 44, 339-351.
Dollahite, D. C., \& Lambert, N. M. (2007). Forsaking all others: How religious involvement promotes marital fidelity in Christian, Jewish, and Muslim couples. Review of Religious Research, 48, 290307.

Dollahite, D. C., Layton, E., Bahr, H. M., Walker, A. B., \& Thatcher, J. Y. (2009). Giving up something good for something better: Sacred sacrifices made by religious youth. Journal of Adolescent Research, 24, 691-725.

Dollahite, D. C., \& Marks, L. D. (2009). A conceptual model of family and religious processes in highly religious families. Review of Religious Research, 50, 373-391.

Dollahite, D. C., Marks, L. D., \& Goodman, M. (2004). Religiosity and families: Relational and spiritual linkages in a diverse and dynamic cultural context. In M. J. Coleman \& L. H. Ganong (Eds.), The handbook of contemporary families (pp. 411431). Thousand Oaks, CA: Sage.

Dollahite, D. C., Marks, L. D., \& Olson, M. M. (1998). Faithful fathering in trying times: Religious beliefs and practices of Latter-day Saint fathers of children with special needs. The Journal of Men's Studies, 7, 71-94.

Dollahite, D. C., \& Thatcher, J. Y. (2008). Talking about religion: How religious youth and parents discuss their faith. Journal of Adolescent Research, 23, 611-641.

Goodman, M. A., \& Dollahite, D. C. (2006). How religious couples perceive the influence of God in their marriage. Review of Religious Research, 48, 141-155.

Hadaway, C. K., Marler, P. L., \& Chavez, M. (1993). What the polls don't show: A closer look at U.S. church attendance. American Sociological Review, 58, 741-752.

Handel, G. (1996). Family worlds and qualitative family research: Emergence and prospects of whole-family methodology. Marriage and Family Review, 24, 335-348.

Hummer, R., Rogers, R., Nam, C., \& Ellison, C. G. (1999). Religious involvement and U.S. adult mortality. Demography, 36, 273-285.

Josselson, R. J., \& Lieblich, A. (1993). The narrative study of lives (Vol. 1). Newbury Park, CA: Sage.

Kaufman, D. R. (1991). Rachel's daughters: Newly Orthodox Jewish women. New Brunswick, NJ: Rutgers.

Koenig, H. G., McCollough, M. E., \& Larson, D. B. (Eds.) (2001). Handbook of religion and health. New York: Oxford University Press.

Lambert, N. M., \& Dollahite, D. C. (2006). How religiosity helps couples prevent, resolve, and overcome marital conflict. Family Relations, 55, 439-449. 
Lambert, N. M., \& Dollahite, D. C. (2008). The threefold cord: Marital commitment in religious couples. Journal of Family Issues, 29, 592-614.

Lambert, N. M., \& Dollahite, D. C. (2010). Development of the Faith Activities in the Home Scale (FAITHS). Journal of Family Issues, 31, 14421464.

Layton, E., Dollahite, D. C., \& Hardy, S. A. (2011). Anchors of religious commitment in adolescents. Journal of Adolescent Research, 26, 381-413. DOI 10.1177/0743558410391260

Lee, J. W., Rice, G. T., \& Gillespie, V. B. (1997). Family worship patterns and their correlation with adolescent behavior and beliefs. Journal for the Scientific Study of Religion, 36, 372-381.

Lehrer, E. L., \& Chiswick, C. U. (1993). Religion as a determinant of marital stability. Demography, 30, 385-403.

Mahoney, A. (2010). Religion in the home 1999 to 2009: A relational spirituality perspective. Journal of Marriage and Family, 72, 805-827.

Mahoney, A., Pargament, K. I., Tarakeshwar, N., \& Swank, A. B. (2001). Religion in the home in the 1980s and 90s: A meta-analytic review and conceptual analyses of links between religion, marriage and parenting. Journal of Family Psychology, 15, 559-596.

Marks, L. D. (2004). Sacred practices in highly religious families: Christian, Jewish, Mormon, and Muslim perspectives. Family Process, 43, $217-$ 231.

Marks, L. D. (2005a). Religion and bio-psycho-social health: PRIVATE A review and conceptual model. Journal of Religion and Health, 44, 173-186.

Marks, L. D. (2005b). How does religion influence marriage?: Christian, Jewish, Mormon, and Muslim perspectives. Marriage and Family Review, 38, 85-111.

Marks, L. D. (2006). Religion and family relational health: An overview and conceptual model. Journal of Religion and Health, 45, 603-618.

Marks, L. D., \& Dollahite, D. C. (2001). Religion, relationships, and responsible fathering in Latterday Saint families of children with special needs.
Journal of Social and Personal Relationships, 18, 625-650.

Marks, L. D., \& Dollahite, D. C. (2007). Turning the hearts of fathers to their children: Why religious involvement can make a difference. In S. E. Brotherson, \& J. M. White (Eds.), Why fathers count (pp. 335-351). Harriman, TN: Men's Studies Press.

Marks, L. D., Dollahite, D. C., \& Baumgartner, J. (2010). In God we trust: Qualitative findings on finances, family, and faith from a diverse sample of U.S. families. Family Relations, 59, 439-452.

Marks, L. D., Nesteruk, O., Swanson, M., Garrison, M. E. B., \& Davis, T. (2005). Religion and health among African Americans: A qualitative examination. Research on Aging, 27, 447-474.

Miller, W. R., \& Thoresen, C. (2003). Spirituality, religion, and health: An emerging research field. American Psychologist, 58, 24-35.

Nelson, J. M. (2009). Psychology, religion, and spirituality. New York: Springer.

Ozorak, E. W. (1996). The power but not the glory: How women empower themselves through religion. Journal for the Scientific Study of Religion, 35, 17-29.

Palkovitz, R. (2002). Provisional balances: The dynamics of involved fathering and men's adult development. Hillsdale, NJ: Erlbaum.

Paloutzian, R. F., \& Park, C. L. (2005). Handbook of the psychology of religion and spirituality. New York: Guilford Press.

Silk, M., \& Walsh, A. (2006). Religion by region: Religion and public life in the United States. AltaMira: Blue Ridge Summit, PA.

Stark, R., \& Finke, R. (2000). Acts of faith: Explaining the human side of religion. Berkeley, CA: University of California Press.

Thomas, D. L. (Ed.). (1988). The religion and family connection: Social science perspectives. Provo, UT: Religious Studies Center.

Received April 30, 2009

Revision received April 28, 2010

Accepted October 7, 2010

\section{E-Mail Notification of Your Latest Issue Online!}

Would you like to know when the next issue of your favorite APA journal will be available online? This service is now available to you. Sign up at http://notify.apa.org/ and you will be notified by e-mail when issues of interest to you become available! 